\begin{abstract}
Research Article
(C) 2021 Anjad A. Mahasneh and Hana Bashayreh. This is an open access article licensed under the Creative Commons Attribution-NonCommercial 4.o International License

(https://creativecommons.org/licenses/by-nc/4.o/)
\end{abstract}

\title{
A Semiotic Translation of Memes: Trump's Visit to Saudi Arabia as a Case Study
}

\author{
Anjad A. Mahasneh \\ Hana Bashayreh \\ Translation Department, \\ Yarmouk University, \\ Jordan
}

DOI: https://doi.org/10.36941/ajis-2021-0o96

\begin{abstract}
This study examines the semiotic translation of memes and their emergence as a new genre of items or entertainment that is becoming rapidly publicized across various social media platforms, such as Facebook and Instagram, among others. The researchers used Saussure's signifier for the translation of the semiotic relationship between images, text and meanings in the examination of six randomly selected internet memes about Donald Trump's visit to Saudi Arabia in 2017. The study results revealed that internet memes do not only transmit a variety of meanings but also convey expressive social and political messages. In addition, the study found that memes deliver entertainment and drive social media users to express common reactions. It was also found that memes affect the language, thoughts, and cultural concepts of any given nation.
\end{abstract}

Keywords: Internet memes, semiotics, translation, Saussure, signs, Trump

\section{Introduction}

According to the "Merriam Webster online dictionary" memes can be defined as "an idea, behavior, style, or usage that spreads from person to person within a culture." However, it is the second description by this dictionary that most serves the aim of this study: "An amusing or interesting item (such as a captioned picture or video) or genre of items that is spread widely online especially through social media." Memes are seen as relics of humor and tend to become viral on social media and spread rapidly through online communication platforms. Subsequently, they are regarded as a separate genre. Wiggins \& Bowers (2014) introduce three types of meme genres: meme, emergent meme, and spreadable media. According to them, spreadable media are multimedia messages that are consumed without being altered and are not limited to online platforms, but can be interpreted through a wide variety of communication channels $(2014,12)$. While emergent memes are spreadable, changeable, and reproducible media that can also be satirized (2014, 12), memes are created when receivers in digital culture produce "imitations, remixes and further iterations of the emergent meme. [They] are diffused rapidly online, especially via online social networks" $(2014,7)$.

Subsequently, it is almost impossible to scroll through social media without seeing memes tackling various topics, ranging from humorous to political content. Considering this, it seems to be evident that humorous political memes raise awareness of political situations, shift the attention of 
young generations to current events and affect their political orientations and beliefs. It also educates and leads the receptors of the memes to follow up on political events; the public's attitudes; and people's political and social positions in a way no other media can do, including articles, news, speeches and ordinary social media posts.

This study discusses certain memes about Donald Trump's visit to Saudi Arabia in 2017 that have widely spread between Arabian and foreign social media users. The aim is to study the connections between images, texts, and the semiotic meanings thereof. Memes usually transfer different meanings and convey various social and political messages. Sometimes they express universal emotions, other times they are only created to humor and entertain social media users. Every meme has its own theme. As such, memes always allow users to come up with innovative and creative ideas to deliver their messages. The significance of this study stems first from the fact that it aims to analyze these memes through semiotics in general and through Saussure's signifier for the translation of the semiotic relationship between images, text and meanings in particular. This study is a novel one in this emerging genre (memes), as the previous studies discussed in this paper show, there is not enough studies yet about this topic. This study is also important because it serves to acquaint linguists and translators on the interconnection of images, texts and art, thus, through the creation of meaning and messages, becoming a new way of communication.

\section{Previous Studies}

Many studies have engaged in the semiotic analysis of memes. De Saussure and C.S. Peirce were the first linguists to introduce semiotic theory. Other known linguists in this field include Noam Chomsky, Umberto Eco, R. Barthes and Jean Baudrillard. Chandler (2017) but for the sake of this paper only the Saussurean and the Peircean definitions are discussed. The approaches of these linguists are dependent on their methodologies, in which there is a differentiation between the Saussurean and the Peircean definitions of semiotics. Saussure's 'semiology' is 'a science that studies the role of signs as part of social life.' Charles Peirce examined this domain of scientific study and called it 'semeiotic' (or 'semiotic'), which was the name for the 'formal doctrine of signs,' and showed a close association with logic (p.16). To understand the intended meaning of an item through semiotic analysis, the hidden signs or symbolism that already exist within the item should be decoded. "If the object could be known directly, there would be no need of a sign to represent it" (Saussure 1966, 31).

"Internet memes as internet signs: A semiotic view of digital culture", a renowned article written by Sara Cannizzaro in 2016, adopts this semiotic theory. Cannizzaro study's the relations between Internet memes that Internet users find and use in daily life and analyzes the nature and extent of the users' attraction to them. This is done by deconstructing the nature, meaning, and purpose of the internet memes. Analysis is conducted particularly on how the relation between images, text, and meanings connect with each other to form social or political messages, universal emotions, or even just to be funny and entertain its users. The author had a close reading of the celebrated 2011 Internet meme Rebecca Black's Friday, and they decoded the relation between images, texts, and meanings using semiotics. She aimed to show that the origins of the confusion surrounding the theoretical status of the internet can be found in Richard Dawkin's theory of culture, as proposed in the Selfish Gene (1976) and later developed in memetics "the science of memes". This article provides an alternative to the atomic and transmissible view of cultural information: that is, a view on the study of memes that draws on biosemiotics and cyber semiotics, Tartu-Moscow semiotics and Peircean semiotics. Due to this change in perspective on memes, it is argued that contemporary internet memes in digital culture should be theorized as sign-systems with the inclination to change in in translation and adopt new meaning that effect behavior, this is in turn, characterized by 'asymmetry' and 'invariancy'. The semiotic analysis of the Rebecca Black's Friday internet meme (YouTube 2011) shows that the adoption of this framework enables one to identify and analyze key moments in the development of a specific internet meme. This is considered a development that may establish 
ground for further investigation in the semiotics of digital culture as a whole.

In his article "The Meme as Post-Political Communication Form: A Semiotic Analysis" Yopak (2018) adopted this semiotic theory and provided an analysis of political memes. The 2016 American Presidential Election is referenced to highlight the importance of memes and online communication in general. The semiotic model was used to contextualize the political and social effects of memetic communication. The researcher concluded that the new media form unfolds by connecting the semiotic model of the meme with the political theories of Chantal Mouffe and Hannah Arendt that discuss the potential for change. Due to the contemporary nature of his study, most of the literature discussed by Yopak (2018) involuntarily relates to his work. Richard Dawkins theorizes memetic communication originally developed from the application of the logic of evolution to cultural information. He focuses more on online phenomena that do not share many similarities with the Dawkins theory.

Moreover, in 2013, Brown studied how web culture uses memes to spread and manipulate ideas. In his opinion, memes should be separated into two categories, humorist and social commentary. These two categories are classified by the cultural context in which the content is created. Hence, he presented a pristine example of how manipulation works in the media. Starting from funny cat photos "LOL" CATS to political memes, as seen in the examples below. A specific example of this can be seen in a music video that shows the U.S President George W. Bush exchanging insults with Senator John Kerry. According to Yopak (2018), a person's culture of dictates the type of memes that person likes. This is because people are inclined to fundamentally share memes that relate to their experience of life, which is culturally driven, regardless of whether they are liberal or a conservative, middle aged or teenagers. Through websites, social media, blogs, wiki, and streaming video sites, Internet users are able to use images, text, and audio to create and develop both insightful and outrageous depictions of their culture.

In the same context, Milner discusses and explores internet memes as public discourse in his dissertation in 2012. At the end of his research, he concluded that memes were a means to transform established cultural texts into new ones, to negotiate the worth of diverse identities, and to engage in unconventional arguments about public policy and current events. Memes reflected a mix of old inequalities and new participation.

Osterroth (2018) studied the semiotics of internet memes from a semantic and pragmatic point of view. He argues that internet memes are not fully investigated across all disciplines. Furthermore, he stresses that internet memes come into existence because social media users share, alter and vary it in many ways. There is no ground for an argument that all internet memes are created by one author or come from one source/ This means that they emerge through collective semiosis. The conceptualization of memes, need to be born from the emergence of a situation, i.e. they need a semantic frame to be understood. Osterroth also presents the term "Memesphere." He defines it as "a very closed semantic/pragmatic net; it is when the memes are comprehended by other outsiders of the culture" (p. 3). Internet memes can be widely customized and applied to various contexts, such as the educational sphere. However, political ones are widely used and easily shared. Due to their executive power and ability to semiotically deliver critical messages, they were banned in various countries.

Kariko (2012) presents a definition for memes with a short history of how they evolved. He adds important information about the fact that creativity, art, messages, and humor can be found and combined in memes. The meaning of memes can be made clear through their imagery captions or texts. However, "[memes] can be interpreted and customized anyway the user wants [them]" (Kariko 2012, 197). Consequently, and based on the studies discussed above, in order to understand memes, both pictures and the language content in them need to be analyzed. The creativity in the creation of memes emerge from their dependence on symbols, words and context, especially when we cultural contexts produce meaning in them. Furthermore, memes are open to multiple interpretations. This makes them a rich material for studying, which is one of the main objectives of this study.

\section{Design and Method}

The concept of intersemiotic translation was used first by Jacobson (1959) as one of the main possible types of translation; intersemiotic translation (transmutation) is defined as "the interpretation of 
verbal signs through a nonverbal sign system", for example, the transmutation from a literary text to a painting, or a film, or a piece of music. According to Aguiar and Queiroz (2010) intersemiotic translation is basically considered to be a semiotic process, as with any translation process. Semiotics is the general science of communication through signs and sign systems, and was introduced by Ferdinand de Saussure (1966). A sign consists of the signifier and the signified. According to Saussure, a sign has two faces, the signifier "sound-image" and the signified "concept" and the relation between them is arbitrary. The process of translation at the verbal level involves translating the signifier into its relating signified in many different languages."What makes translation possible is the arbitrary relation between the signifier and the signified, the signifier could be changed (translated) for the relating signified, using different languages" (Mahasneh, 2016, p.268). In an intersemiotic translation context, the non-verbal sign, or the source language signified is replaced by another verbal or nonverbal signified in the target language. This means that there is no signifier in this case. Consider, for example, this road sign:

\section{( STOP) could be translated into Arabic as (ف) , or into French as ( ARRE) ).}

Furthermore, a sign is a combination of the form it takes (technically the 'sign vehicle', such as a word or image) and the meaning interpreted from it (Chandler 2017, 12). Signs can exist in many different forms. For example, "from the features or the signifiers of every meme, the signified or the abstract concept can be known and can lead to the meaning of the meme. Memes have different signifiers that lead to a different signified, and different function when they are used in posts (Sayani 2013, 9).

Further, through semiotics one can understand the association between signs and the meanings they communicate to their interpreters. Saussure argues that the signifier could have many forms, such as pictures, words, or sounds. Similarly, the signified, as he argues, is the notion or meaning that the signifier represents or expresses (Bradley 2018).

In particular, the study involves a political, social, and humorous analysis of six randomly selected samples of internet memes about Trump's visit to Saudi Arabia in 2017, three with Arabic captions and three with English ones. The memes have been publicized by many social media networks, such as Facebook, Instagram, Twitter, etc. The images displayed in the memes show Trump with the humorous descriptions of him. Since internet memes are classified as signs, a semiotic analysis of Saussure signified and signifier concepts of the selected samples is carried out to show how the memes in question and their captions have been used to impart political messages and provide entertainment to the readers.

\section{Discussion}

The Saussure signifier and signified notions are employed in the following is discussion of the six memes about Trump's visit to Saudi Arabia. As stated by Sayani (2013) any meme can have more than one signifier and more than one signified as is evident in the following examples:

\subsection{Analysis of meme one}

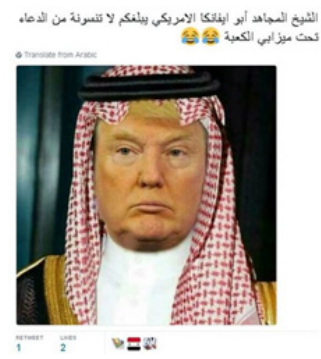

Figure 1: 
As the figure shows, the meme consists of an Arabic caption above an image.

The Arabic text - "الثيخ المجاهد أبو ايفانكا الأمريكي يبلغكم لا تنسونه من الدعاء تحت ميز ابي الكعبة" means: The Muslim warrior, Ivanka's American father, asks you to pray for him at the Kaábah (The Holy Mosque).

a) Top text: The caption above the image is the first signified. This Arabic sentence can be interpreted as such: Alsheikh Almujahid (the holy warrior), Ivanka's father, requests people (Muslims) to invoke the blessings of God upon him at the Kaábah (The Holy Mosque). The second signified is the concept of mocking the American president.

b) Image: the image (the picture) of the American president, Donald Trump and what he is wearing is the signifier. He is depicted as a Saudi sheikh (chief) wearing a traditional Arabic dress consisting of a white gown, a cloak, and a head cover (ghutra). His facial expression indicates the strictness of tribal chiefs.

\subsubsection{Interpretation}

The collective meaning of the image and the text became clear after combining the signifier and the two signifieds. The Arabic text on top of the image is one signified and the sarcastic comment on the degraded political situation of the Arabs following Trump's visit to Saudi Arabia is another. It creates entertainment as it evokes laughter about Trump being dressed like Saudi people, and about the sternness of his face, a feature characterizing Saudi religious people. This meme is meant to be entertaining; however, it imparts a serious message: the Arabs are illusioned if they think that Trump will someday become a Muslim sheikh siding with the Arabs and minding their causes.

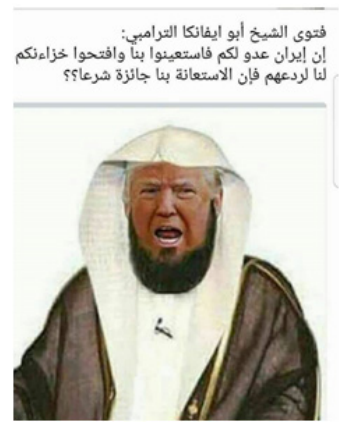

Figure 2:

As the figure indicates, the meme includes an image of Trump, with Arabic text as the caption. The

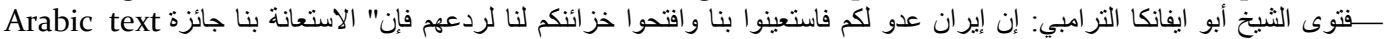
ـ شرعا؟؟", means: a religious verdict (fatwa) given by Ivanka's father, Trump, stating: Iran is your enemy. Seek our assistance and open your treasures for us, since seeking our assistance is religiously approved.

a) Top text: The Arabic caption above the image (picture) is the first signified. This text satirizes Trump, who is depicted as a Muslim sheikh that is preoccupied with preaching (signified two).

b) Image: The image (picture) shows Trump as an Imam (leader) of Muslims, wearing a traditional Arabic dress (called Abaya) that is usually worn by Imams. This is the signifier. Trump is depicted with a growing beard as is normal for Muslim Imams to do. There is a small black microphone on his chest. There is also a white ghutra (head cover) on his head. 


\subsubsection{Interpretation}

The meme under discussion is an ironic comment on the deluded Arabs who are willing to trust a non-Muslim person, like Trump, and seek his assistance. As the meme suggests, Trump has been delineated as a Muslim Imam, which is meant to ridicule him. Ironically, Trump declares that Iran (which is a Muslim country) is the enemy of Saudi Arabia, thus turning a Muslim country against another Muslim country. Consequently, the Saudi people should act upon Trump's advice and seek the aid and protection of the Americans to fight Iran. It is also ironic that Trump asserts that Islamic laws (Sharia) permit seeking the assistance of Americans (non-Muslims). Trump also asks Saudis to open their treasures for Americans in return for their assistance. In this regard, the meme above conceptually implies the conveyance of an important message to the Arabs, warning them not to accept aid from non-Muslims to fight their fellow Muslims (Iranians). It also implies that the Arabs should wake up to the bitter reality that the Americans want to drain their money.

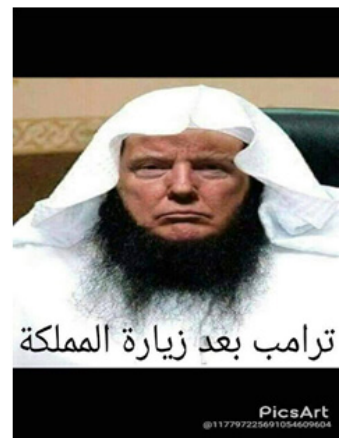

Figure (3)

The third meme comprises of a picture of the American President, Donald Trump who is depicted as a Saudi leader and a caption in Arabic at the bottom of the meme. The Arabic text - ترامب بعدزيارة "المملكة" means: Trump following the visit to the Kingdom.

a) Bottom text: The caption underneath the image is the first signified; the American president after his visit to Saudi Arabia, became a leading Muslim sheikh. The second signified is a concept that serves as an implicit mock at not only Trump himself but also the Saudis.

b) Image: The image (picture) which shows Trump as a long-black-bearded Muslim Imam is the signifier. He is depicted as one of the Holy mosque's imams. He wears the traditional Arabic dress, a white ghutra, and a long white thobe. His mouth is shut, and his facial expression indicates his reverence, dignity, and the strictness of tribal chiefs.

\subsubsection{Interpretation}

This image shows Trump as a religious Imam who leads Muslims in their prayers. He has become a true religious leader. This could signify that he did this for the sake of befooling all Muslims, or Saudis in this case, and to take their money. Just like the English play She Stoops to Conquer; Trump pretends to be an imam to fool the Saudis since he knows that Saudis adhere to the words of the imams. The Saudi people obey the imams and never show any sign of disrespect toward them. Therefore, the significance of this image stems from the way the miniaturist (creator of the meme) 
depicts Trump. This depiction could point to political and religious messages that the miniaturist wants to convey to the reader.

In conclusion, we may say that the three memes discussed above, in conjunction with their captions, create a conceptual meaning that is in line with how the Arabs felt after Trump's visit to Saudi Arabia. They felt that they have been mocked or even politically degraded. The feeling associated with the memes and the captions are combined to not only serve as entertainment but also communicate political sarcasm.

4.4 Analysis of meme four

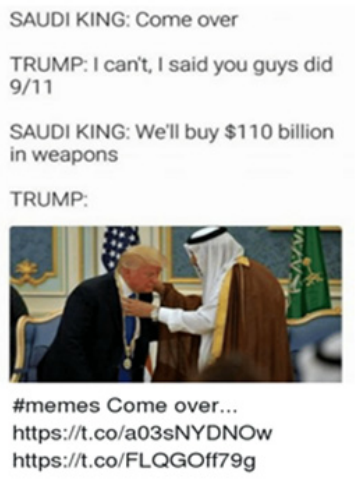

Figure 4:

As seen in the figure, this meme includes English text with an image of Trump and King Salman. The English text displays dialogue between King Salman and Trump. King Salman requests Trump to come over but the latter said that he could not since Saudis have been accused of being the executers of the terrorist events of $9 / 11$.

a) Top text: The caption above the image represents the first signified; i.e. a dialogue between King Salman and Trump about Trump's visit to Saudi Arabi. Trump rejected this invitation by King Salman at first; but when the King told him that Saudi Arabia will offer him 110 billion US Dollars in the form of weapons, Trump could not resist. The second signified ridicules Trump, who is depicted as a good political negotiator and an economist who could do anything for the sake of money.

b) Image: The image is the signifier. It was taken in the palace of King Salman and shows Trump bowing to King Salman to be awarded a golden medal. King Salman wears the traditional Saudi dress and the American and Saudi flags are behind them.

\subsubsection{Interpretation}

This meme is an ironic comment targeting the Arabs. Trump is shown bowing to King Salman to be awarded a golden medal. The image shows a dialogue between Trump and King Salman. King Salman asks Trump to come and visit. Trump, at first, refuses King Salman's invitation and replied that Saudis are convicted of being responsible for the event of 9/11/2001, and for this reason, he cannot visit Saudi Arabia. In the second dialogue, knowing that Trump is a successful businessman, King Salman entices Trump by offering him money, saying that Saudi Arabia would buy weapons for 110 billion US Dollars. Trump could not resist. Upon this financially political seduction, Trump accepts King Salman's invitation and bowed down to King Salman who presented him with a golden medal. Thus, through this meme, a politically sarcastic connotative meaning is communicated to the public. 


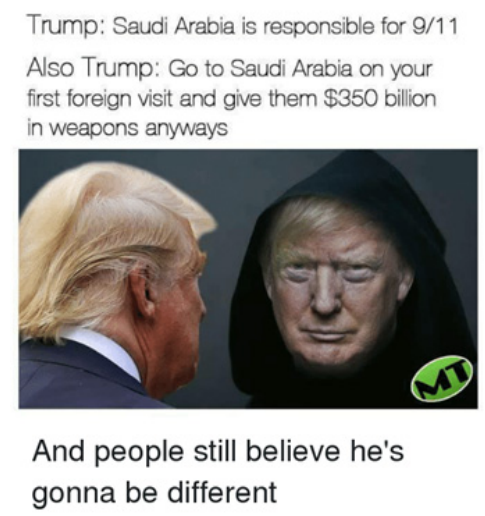

\section{Figure 5:}

Figure five is a meme that includes dialogue in English and an image of Trump speaking to his devil self. The English text reveals this dialogue

a) Top text: The caption above the image represents the first signified, which is a dialogue between Trump and his devil self, concerning the former's visit to Saudi Arabi and the seizing of their money. The second signified here is the concept that ridicules Trump's nature. He is depicted as a man who would disregard anything and go for money.

b) Bottom text: The third signified is the caption at the bottom of the image which shows the irony behind this meme. It is written in English and points to Trump's ability to disguise his real intentions.

c) Image: The image is the signifier. It shows two characters, the real Trump and the devil one.

\subsubsection{Interpretation}

In this meme Trump is depicted speaking to his devil self. The dialogue has a sarcastic, political, and economic connotation, which, if explained or communicated to the public, would receive a lot of comments and remarks from the Arab critics, especially from those interested in such political issues. Trump, in this meme represents a realistic president who refuses the invitation of King Salman because Saudis are declared, according to American officials, responsible for the event of 9/11. The picture and the text communicate a political message of a a malevolent person appearing to be friendly until the opportunity to cause harm is given. The situational irony and the funny remarks shown in the picture communicate two apparently different personalities, but, in fact, they are the same. The good character, represented by the American president, Donald Trump, and the evil character, represented by the other Trump. Trump seems to be a good American president and, therefore, acts for the good of America by first refusing to accept the Saudi King's invitation. Nevertheless, the other Trump speaks to him asking him to visit Saudi Arabia and to take their money by selling them weapons valued at 350 billion US Dollars. Ironically, the meme shows that both faces are identical and have the same attitude despite what others believe them to be. 


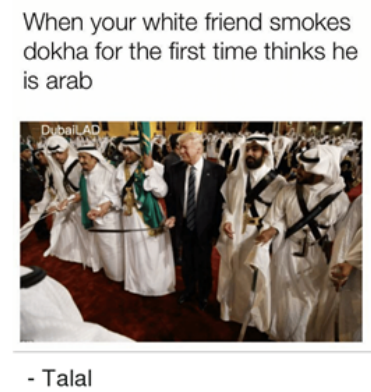

Figure 6:

The meme in Figure 6 shows Trump with Saudi King Salman and other Saudi officials. Trump is surrounded by Saudis performing Ardah, a traditional dance of the central region of Saudi Arabia.

a) Top text: The English caption above the image is the first signified. It mentions that should a white, non-Arab smoke dokha, he thinks that he has become an Arab. The second signified is the concept that ridicules Trump who thinks that he has become a Saudi.

b) Image: The image is the signifier. It shows Trump wearing a black suit and white shirt. He is surrounded by King Salman and other Saudi officials who perform their national dance called Ardah. Trump and all the Saudis are holding their swords. The Saudis wear their traditional dresses.

\subsubsection{Interpretation}

This meme shows Trump along with Saudi King Salman and other Saudi officials. Trump is surrounded by Saudi officials performing the Ardah, a traditional dance of the central region of Saudi Arabia. This traditional dance is held annually on September 23 on the traditional celebration, Saudi National Day, as well as some other traditional celebrations and occasions. This traditional dance is politicized in this meme, especially within the context of Trump visiting Saudi Arabia. Saudis wear a special dress during this celebration, as the picture shows, while Trump wears his formal suit. He also holds a sword, which is one of the essential tools used by Saudis in this dance. Talal, the Arab person who fabricated this picture passes his sarcastic comments on the picture saying, "When your white friend smokes dokha for the first time, he thinks he is Arab." Talal wants to communicate to the public that whenever non-Arabs come to visit Arab countries, or their apparently Arab friends, they behave just like Arabs. Trump has smoked 'dokha,' a special product of Arabian tobacco, which consists of superbly dried tattered tobacco bits mixed with some spices and herbs. After smoking 'dokha,' Trump behaves like the Saudis on this special occasion. Culturally speaking, Trump acts as the known proverb says, "When in Rome, do as the Romans do." It means that when a person is in an unfamiliar situation or a foreign country, he or she should adopt local practices and etiquette.

Such a visual expression is humorous and communicates a political message to the rest of the world. If anyone wants anything from others, they should mimic them so that they can get what they want. This is what the memes here shows; Trump behaves like Saudis and gets what he wants easily. There is a common English proverb about flattery and deception that reads as such: "Flattery is like friendship in show, but not in fruit." This proverb may best describe this humorous situation. It is ironical that a deceptive enemy behaves like a good friend and snatches away whatever he or she desires. Evidently, the third, fourth and fifth memes and their satiric captions serve to point to and communicate some political and satirical comments. 


\section{Results and Discussion}

Memes are a new emerging genre on social media platforms and needs further investigations from a semiotic translation perspective. Memes could have a worldwide effect on language, thoughts, and cultural concepts of human beings. Their influence could spread very quickly, which could lead them to cross all linguistic barriers. Until recently, not much has been written about memes or their communicative meaning, especially with regards to translation studies. Moreover, memes are considered a new way of trans- creating the history and the culture in this globalized world.

In addition to the above, internet memes serve as a political and humorous tool for authors to impart funny and sarcastic remarks to the readers. It could be said that images with captions might communicate different political or social ideas aside from inherited humorous meanings. This is due to them being interpreted in accordance with a specific theme and, thus, their meaning might change in different contexts. As with other forms of language, internet memes contain language expressions which are similar to the function of translation where a particular meaning in a source language is translated into an equivalent one in the target language. It is, therefore, concluded that through the translation of memes, a variety of meanings could be conveyed worldwide. Every meme could have more than one signifier and more than one signified, i.e. a meme might convey more than one meaning.

Further, this study resorts to the semiotic theory (Saussure) to analyze the qualitative data that have been randomly collected from different internet websites. Not only because it examines the political and the cultural contents of any given memes but also because it communicates their multiple meanings to all cultures across the world. Thus, allows memes to cross any linguistic barrier. The results also show that Semiotic theories, including Saussure's and Peircean definitions of semiotics (signifier and signified) and Jacobson's intersemiotic translation are the most appropriate theories by which to study memes (Mahasneh, forthcoming).

Finally, the current study was limited to internet memes about Trump's visit to Saudi Arabia. Although this study references existing research, it functions as in introductory concept to be further analyzed in future research and could, thereby, contribute to the advancement of the understanding of semiotics in an evolving digital culture. Therefore, the researchers suggest that further research should be conducted to investigate the applicability of such semiotic analysis of memes related to a different topic.

\section{References}

Aguiar, D., \& João, Q. (2010). Modeling intersemiotic translation: Notes toward a Peircean approach." AS/SA 9.24: 68-81.

Bradley, S. (2018). An Introduction To Semiotics - Signifier And Signified. Retrieved December 14, 2018, from: https://vanseodesign.com/web-design/semiotics-signifier-signified/

Brown, G. (2013). Web Culture: Using Memes to Spread and Manipulate Ideas on a Massive Scale. Interface: The Journal of Education, Community and Values 13.187-193

Cannizzaro, S. (2016). Internet memes as internet signs: A semiotic view of digital culture. $\Sigma \eta \mu \varepsilon \iota \omega \tau \kappa \eta ́-S i g n ~ S y s t e m s$ Studies 44.4: 562-586.

Chandler, D. (2017). Semiotics: the basics. Routledge: Taylor \& Francis Group London and New York.

Dawkins, R. (1976). The Selfish Gene. Oxford: Oxford University Press.

De Saussure, F. (1966). Course in general linguistics: Ferdinand de Saussure. New York : McGraw-Hill Book Co.

Druce, P. (2017). The meme-ing of life: viral humor and why it spreads. University of Melbourne. Access date: 18/ 10/2018. blogs.unimelb.edu.au

Jacobson, R. (1959). On Linguistic Aspects of Translation, in Brower, (ed.). On Translation, Cambridge, MA: Harvard University Press, pp. 232-239.

Kariko, A. T. (2012). Humorous writing exercise using Internet Memes on English classes. Lingua Cultural Journal 6.2: 188-199.

Mahasneh, A. (2016). Arabic Language and Emotiveness's Translation. International Journal of Social Science and Humanity. 6: 268-274. DOI: 10.7763/IJSSH.2016.V6.656 
Milner, R. (2012). The world made meme: Discourse and identity in participatory media. Diss. University of Kansas.

Osterroth, A. (2018). Semiotics of Internet Memes. University of Koblenz-Landau, Germany. DOI 10.13140/RG.2.2.12320.89605.

Rutherford, A. (2009). Beyond the Box: BF Skinner's technology of behaviour from laboratory to life, 1950 -1970s. University of Toronto Press.

Sayani, M. N. (2013). Semiotic Analysis of Memes in 9GAG.com. Humanis. Retrieved 2 November 2018 from: https://ojs.unud.ac.id/index.php/sastra/article/view/5005

Wiggins, B. \& Bowers, B. (2014). Memes as genre: A structurational analysis of the memescape. New Media $\mathcal{E}$ Society 17(11) : 1886-1906. DOI: 10.1177/1461444814535194

Yopak, J. (2018). The Meme as Post-Political Communication Form: A Semiotic Analysis. University of Vermont.

\section{Appendix 1:}

\section{List of Figures Used in this Paper}

In this paper, the researchers have used 6 Internet memes with captions of both Arabic and English languages. Below is a list and a brief description of the figures used in this study.

\begin{tabular}{|l|l|l|}
\hline No. & Figure Title & Source \\
\hline 1 & $\begin{array}{l}\text { Leading Muslim Mujahid named the American Mujahid } \\
\text { Sheikh Abu Ivanka salutes all Arabs }\end{array}$ & http://www.bbc.com/arabic/trending-39538468 \\
\hline $\mathbf{2}$ & Trump as a Muslim Imam & https://twitter.com/almhalig82224 \\
\hline 3 & Trump after visiting Saudi Arabia & http://elbashayeronline.com/news-828065.html \\
\hline 4 & Trump and King Salman & https://me.me/s/trump\%2oin\%20saudi \\
\hline 5 & Trump and the other side of Trump & $\begin{array}{l}\text { https://www.reddit.com/r/MarchAgainstTrump/comments/ } \\
\text { 6denq9/trumps_first_foreign_trip/ }\end{array}$ \\
\hline 6 & Trump dancing Ardah & http://www.e227.info/talal-memes.html \\
\hline
\end{tabular}

